\title{
Determination of some quality properties of marinated sea bream (Sparus Aurata L., 1758) during cold storage
}

\author{
Gülderen Kurt KAYA ${ }^{1 *}$ Özden BAŞTÜRK²
}

\begin{abstract}
In this study, it was aimed to determine the effect of sea bream (Sparus aurata) marinated some quality properties during cold storage. The fillets of fish were immersed into brine including 3.5\% acetic acid $11 \%$ salt in the ratio of 1: 1.5 (fish: marinate brine) for marination process. After the process of ripening, samples were grouped into two and packed in plastic containers; one being plain (in sunflower oil) and the other being sauced (sauced prepared with sunflower oil). During storage, sensory, crude protein, lipid, dry matter and crude ash, TBA, TVB-N, TMA-N and peroxide analyses were done periodically. According to results of 200 days of storage, TVB-N values of sea bream marinates packaged as plain and sauced were $15.86 / 14.89 \mathrm{mg} / 100 \mathrm{~g}$, TBA 7.06/7.99 mg MA/kg, TMA-N 2.97/3.12, mg/100g, the value of peroxide was 7.23/7.45 meq $/ \mathrm{kg}$ respectively. According to chemical and sensory analyses results obtained in the study; it was concluded that sea bream marinates packaged as plain and sauced can be stored in $+4{ }^{\circ} \mathrm{C}$ for 200 days.
\end{abstract}

Keywords: marination; sea bream; Sparus aurata; cold storage; shelf life; quality properties.

Practical Application: Quality of marinated sea bream (Sparus aurata) was determined during 200 days.

\section{Introduction}

Majority of the fish obtained by means of fishing and farming in our country is consumed fresh; this is followed by frozen produce and processed food prepared with other processing techniques. Consumption of processed aquaculture products is beneficial for preservation and storage of the product; this also makes it possible to benefit from the products even further. For this reason, undertaking of studies required for obtaining the maximum yield from available natural resources, in addition to this, exploitation and preservation of the obtained products as best as possible, and presentation of the products to consumption of people have also become important in our country as is the case in other countries.

"Ready to eat" term is used for products which are prepared by applying appropriate processing techniques and preservation methods; have a certain endurance time; are consumed either directly or by heating to eating temperature; and are consumed alone or by processing with certain substances (Pala \& Sayg1, 1987). Marinated products as well are amongst these products prepared in this manner and presented to the consumers' liking. These products, which are obtained by maturation of mainly fish such as anchovies, sardines, and shad fish in vinegar and salt, are consumed with pleasure both in our country and in European countries. These marinades are fish and shellfish products preserved in acetic acid and salt solution to increase the shelf life; they are prepared with additives such as sugar and spices to obtain different flavours, and they are packed in glass jars or plastic containers (Varlık et al., 1993).
The aim of this study is to determine the nutrient composition, chemical quality, and sensory changes of marinated sea bream during cold storage.

\section{Materials and methods}

In this study, a total of $30 \mathrm{~kg}$ sea bream with individual weights of 200-300 g were used. Fish were procured from a private enterprise engaged in fish farm in Mersin. The fish were carried in ice in styropor boxes (Strobuzkap, Onay Machine Co. Inc., Istanbul, Turkey). Initially, the heads of the fish were cut off after being brought to the laboratory; then internal organs were removed, and afterwards, the fish were filleted by experts. Brine prepared with 3.5\% acetic acid (Merck Group, Istanbul) and $11 \%$ salt (Safir industrial salt, Safir, Ankara) was used for the marination process. The samples were prepared at 1:1.5 ratio of fish to brine, placed inside four plastic cans of $10 \mathrm{~L}$ capacity so that each can had $4 \mathrm{~kg}$ of fish. The cans were closed tight and left to mature under refrigeration conditions. After a period of two days of marination, the fish were skinned and put again into the solution. Then the marination period was carried on 24 hours, the marinated fish were drained and divided into two groups. Afterwards they were packed. Leak-proof, air-locked plastic containers (Bora, Istanbul) of $300 \mathrm{ml}$ capacity were used for packing. Each package was filled with $210 \mathrm{~g}$ of fish fillets and $105 \mathrm{ml}$ of sunflower oil to prepare the sea bream in oil (plain = control group). To prepare the sea bream in sauce, each package was filled with $210 \mathrm{~g}$ fish, $100 \mathrm{ml}$ sunflower oil, $4 \mathrm{~g}$ tomato paste, 
$3 \mathrm{~g}$ garlic, and a leaf of dill (group in sauce). All samples were packed and stored at $+4 \pm 1{ }^{\circ} \mathrm{C}$ refrigerator conditions.

After packing, crude protein, lipid, moisture and crude ash, thiobarbituric acid (TBA), total volatile basic nitrogen (TVB-N), trimethylamine nitrogen (TMA-N), peroxide analyses and sensory analyses were conducted on all samples starting from the $0^{\text {th }}$ day of the completion of marination, on the $15^{\text {th }}, 30^{\text {th }}$, and $50^{\text {th }}$ days, and afterwards at monthly periods until the $200^{\text {th }}$ day.

Evaluation of sensory analyses was carried out according to Schormuller (1968) sensory evaluation scheme which was modified by Varlık et al. (1993) with respect to the natural anchovy marinades in sunflower oil. Sensory analyses were undertaken by five experienced panelists considering the categories such as appearance, flavour and texture where they scored the food 1 to 9. In the scoring system, 7-9 indicated "very good", 4.1-6.9 indicated "good", 4 indicated "consumable", 1-3.9 indicated "unacceptable" products. Texture was scored 1 to 4 . The score of 1 denoted as spoiled, the score of 2 indicated "acceptable", the score of 3 indicated "good" quality and the score of 4 indicated "very good" quality.

Crude protein was determined according to Kjeldahl (James, 1995); lipid analysis was performed in accordance with method of Bligh \& Dyer (1959); moisture was determined using the method of Ludorff \& Meyer (1973); crude ash was determined according to Mattissek et al. (1988); thiobarbituric acid (TBA, mg malonaldehyde $/ \mathrm{kg}$ ), analysis was done in accordance with Tarladgis et al. (1960); total volatile basic nitrogen (TVB-N, $\mathrm{mg} / 100 \mathrm{~g}$ ) was determined based on the method applied by Antonacopoulos \& Vyncke (1989) with the distillation operation (Varlık et al., 1993); trimethylamine-nitrogen (TMA-N, mg/100g) (Varlık et al., 2007; Food and Agriculture Organization of the United Nations, 1986) and peroxide value (PV, meq $/ \mathrm{kg}$ ) were determined based on AOAS (American Oil Chemists Society, 1994) methods.

SPSS v.11.5.1 package program was used for statistical analyses. In the statistical analyses, results were considered significant when $\mathrm{P}<0.05$ and $\mathrm{P}<0.01$. Repeated measures analysis of variance was used to examine whether there was a difference in the changes occurred in chemical and sensory data during the follow-up period in terms of the type of packing.

\section{Results and discussion}

The changes in nutrient composition of samples in the study were investigated on the raw material, on the fillets after being marinated, and after being placed inside plastic boxes during the storage period; and the data obtained in the research are given in Table 1.

Crude protein content of raw material was determined to be $16.48 \pm 0.71 \%$; it was $16.24 \pm 1.58 \%$ in each of the two groups of packing on the $0^{\text {th }}$ day of maturation of the marinades; the difference found between the groups was statistically insignificant $(\mathrm{P}>0.05)$. A statistically significant difference was observed between duration and packing type in the marinated sea bream which were packed in sauce and in plain oil $(\mathrm{P}<0.01)$. CP (Crude Protein) \% of sea bream marinades increased in the first 15 days of storage and was determined to be $19.56 \pm 0.37 \%$ for the marinades in sauce and $20.51 \pm 0.37 \%$ for the plain marinades; in the later period the $\mathrm{CP} \%$ increased further and reached $24.78 \pm 0.10 \%$ and $24.43 \pm 1.31 \%$ on the $200^{\text {th }}$ day, respectively. When the groups were compared with respect to the duration of storage, a statistically significant difference was observed on the $140^{\text {th }}$ day $(\mathrm{P}<0.05)$ whereas the difference between other periods was not statistically significant $(\mathrm{P}>0.05)$.

In this study, when values of crude protein in fresh fish were compared with the values obtained after the completion of marination and during the storage, it was concluded that there was no loss of protein and marination process did not lead to any loss of protein in the fish. Özden (2005) did a similar study on marinated anchovy and determined the $\mathrm{CP} \%$ to be $18.02 \pm 0.92 \%$ in fresh fish (raw material) and $19.10 \pm 1.04 \%$ after being marinated. K1lınç \& Çaklı (2004) conducted a study on sardine marinades and determined the crude protein ratio to be $13.2 \pm 0.10 \%$ in raw material and $15.4 \pm 0.31 \%$ in marinated fillets. Cabrer et al. (2002) examined the chemical changes in anchovy marinades during maturation and determined the crude protein percentage to be $17.95 \pm 0.43 \%$ in the raw material and $19.13 \pm 0.98 \%$ in marinated fillets. All these findings are

Table 1. The changes in the proximate composition of marinades during the conservation period.

\begin{tabular}{|c|c|c|c|c|c|c|c|c|}
\hline \multirow{3}{*}{$\begin{array}{l}\text { Storage time } \\
\text { (day) }\end{array}$} & \multicolumn{8}{|c|}{ Food composition in terms of the packing style } \\
\hline & \multicolumn{2}{|c|}{ Crude Protein $(\%)$} & \multicolumn{2}{|c|}{ Lipid (\%) } & \multicolumn{2}{|c|}{ Moisture (\%) } & \multicolumn{2}{|c|}{ Crude Ash (\%) } \\
\hline & Sauced & Plain & Sauced & Plain & Sauced & Plain & Sauced & Plain \\
\hline Raw material & $16.48 \pm 0.71$ & $16.48 \pm 0.71$ & $17.06 \pm 0.37$ & $17.06 \pm 0.37$ & $65.29 \pm 0.42$ & $65.29 \pm 0.42$ & $1.14 \pm 0.10$ & $1.14 \pm 0.10$ \\
\hline 0 & $16.24 \pm 1.58$ & $16.24 \pm 1.58$ & $19.50 \pm 0.58$ & $19.88 \pm 1.15$ & $59.61 \pm 1.98$ & $59.31 \pm 2.49$ & $4.42 \pm 0.06$ & $4.42 \pm 0.06$ \\
\hline 15 & $19.56 \pm 0.37$ & $20.51 \pm 0.40$ & $16.08 \pm 0.33$ & $15.96 \pm 0.37$ & $60.07 \pm 0.61$ & $59.04 \pm 0.59$ & $4.20 \pm 0.06$ & $4.35 \pm 0.10$ \\
\hline 30 & $20.97 \pm 0.53$ & $21.19 \pm 0.33$ & $18.82 \pm 0.48$ & $16.53 \pm 0.37$ & $56.00 \pm 0.36$ & $57.48 \pm 0.44$ & $4.06 \pm 0.05$ & $4.73 \pm 0.05$ \\
\hline 50 & $21.78 \pm 0.34$ & $21.85 \pm 0.09$ & $19.23 \pm 0.62$ & $16.32 \pm 0.09$ & $54.93 \pm 0.43$ & $57.38 \pm 0.26$ & $3.97 \pm 0.06$ & $4.36 \pm 0.21$ \\
\hline 80 & $23.10 \pm 0.45$ & $22.78 \pm 0.10$ & $18.72 \pm 0.42$ & $15.83 \pm 0.39$ & $53.88 \pm 0.71$ & $56.95 \pm 0.29$ & $4.24 \pm 0.05$ & $4.36 \pm 0.14$ \\
\hline 110 & $24.60 \pm 0.59$ & $23.65 \pm 0.59$ & $18.29 \pm 0.28$ & $16.21 \pm 0.12$ & $52.57 \pm 1.30$ & $55.61 \pm 0.59$ & $4.19 \pm 0.07$ & $4.41 \pm 0.08$ \\
\hline 140 & $25.26 \pm 0.76$ & $24.14 \pm 1.39$ & $19.10 \pm 1.63$ & $16.40 \pm 0.80$ & $51.48 \pm 1.99$ & $54.96 \pm 0.57$ & $4.13 \pm 0.10$ & $4.45 \pm 0.08$ \\
\hline 170 & $22.76 \pm 0.81$ & $23.62 \pm 0.77$ & $18.84 \pm 0.85$ & $18.80 \pm 1.02$ & $53.80 \pm 0.11$ & $52.88 \pm 0.81$ & $4.52 \pm 0.10$ & $4.64 \pm 0.11$ \\
\hline 200 & $24.78 \pm 0.10$ & $24.43 \pm 1.31$ & $17.70 \pm 1.72$ & $17.76 \pm 1.19$ & $53.19 \pm 0.64$ & $53.13 \pm 2.39$ & $4.22 \pm 0.06$ & $4.57 \pm 0.03$ \\
\hline
\end{tabular}

$\mathrm{n}=3$; (mean value \pm standard deviation). 
in agreement with the results of our study. In addition, the results obtained in this study are also in agreement with the findings of Cadun et al. (2005, 2008), Kılınç \& Çaklı (2005) and Sallam et al. (2007).

Lipid levels of both the marinades in sauce and the plain marinades dropped sharply on the $15^{\text {th }}$ day; a significant increase was observed in the marinades in sauce in the following days whereas a similar degree of change did not occur in the plain marinades. Percentage lipid levels of the plain marinades and the marinades in sauce did not change much in both groups between the $30^{\text {th }}-140^{\text {th }}$ days of storage; however, on the $200^{\text {th }}$ day, they decreased in the marinades in sauce and increased in the plain marinades and reached $17.76 \pm 1.19 \%$ level. The lipid ratio, which was $17.06 \pm 0.37 \%$ in raw material, was recorded to be $19.88 \pm 1.15 \%$ in the plain groups and $19.50 \pm 0.58 \%$ in the groups in sauce and there was no statistically significant difference between these values $(P>0.05)$. The difference between the $0^{\text {th }}$, $15^{\text {th }}, 170^{\text {th }}$, and $200^{\text {th }}$ days of storage was found to be insignificant $(\mathrm{P}>0.05)$ whereas the difference between the $30^{\text {th }}, 50^{\text {th }}, 80^{\text {th }}, 110^{\text {th }}$, and $140^{\text {th }}$ days was found to be statistically significant $(\mathrm{P}<0.01)$.

The lipid value of $17.06 \pm 0.37 \%$ which was recorded in the raw material of sea bream in our research is close to the lipid value of $15.11 \pm 0.08 \%$ reported by Erkan \& Özden (2007); however it is not in agreement with the lipid value of $9.8 \pm$ $1.36 \%$ determined by Grigorakis et al. (2003). This difference in question is suggested to be depending on the season the fish were caught, the environment in which the fish lived, as well as on the size of the fish; moreover, the content of the feed used is thought to have an effective role to play in this difference.

The moisture content was determined to be $65.29 \pm 0.42 \%$ in the raw material, $59.31 \pm 2.49 \%$ in the groups packed plainly, and $59.6 \pm 1.98 \%$ in the groups packed in sauce; moreover, there was no statistically significant difference between these groups $(\mathrm{P}>0.05)$. During storage, there was no statistically significant difference between the $0^{\text {th }}, 170^{\text {th }}$, and $200^{\text {th }}$ days; however the difference between the $15^{\text {th }}, 30^{\text {th }}, 50^{\text {th }}, 80^{\text {th }}, 110^{\text {th }}$, and $140^{\text {th }}$ days was observed to be statistically significant between the plain group and the group in sauce $(\mathrm{P}<0.01)$. The $\%$ moisture content in the raw material of sea bream found in our study is similar to the value of $63.52 \pm 0.18 \%$ detected by Erkan \& Özden (2007); however, it is not in agreement with the moisture content of $71.20 \pm 2.52 \%$ determined by Grigorakis et al. (2003).

The amount of crude ash was recorded to be $1.14 \pm 0.10 \%$ in the raw material, $4.42 \pm 0.06 \%$ in the marinades packed plainly, and $4.42 \pm 0.06 \%$ in the marinades packed in sauce on the $0^{\text {th }}$ day of maturation and the difference between the groups was not significant $(\mathrm{P}>0.05)$. During storage, the difference between the two groups was found to be statistically significant on the $30^{\text {th }}, 50^{\text {th }}, 110^{\text {th }}, 140^{\text {th }}$, and $200^{\text {th }}$ days $(\mathrm{P}<0.05)$; whereas it was recorded to be not significant on the other days of storage, which were the $0^{\text {th }}, 15^{\text {th }}, 80^{\text {th }}$, and $170^{\text {th }}$ days $(\mathrm{P}>0.05)$. When the changes observed in the $\%$ crude ash ratios of the plain marinades and the marinades in sauce during storage were analyzed, it was detected that the $\%$ ash reached its maximum level in the plain marinades on the $30^{\text {th }}$ day whereas it reached its minimum level in the marinades in sauce on the $50^{\text {th }}$ day. In addition, the changes in the marinades in sauce were determined to be more significant and volatile than the changes in the plain marinades. The crude ash values recorded by Erkan \& Özden (2007) and Grigorakis et al. (2003) are similar to the crude ash results obtained in this research.

Table 2 shows the result of chemical analysis of raw material and sea bream marinades in sauce and plan. The TVB-N was detected to be $21.81 \pm 0.71 \mathrm{mg} / 100 \mathrm{~g}$ in the raw material and it was recorded to be $12.53 \pm 0.05 \mathrm{mg} / 100 \mathrm{~g}$ in the plain marinades and $12.53 \pm 0.05 \mathrm{mg} / 100 \mathrm{~g}$ in the marinades in sauce on the $0^{\text {th }}$ day and the difference between the groups was determined to be not significant $(\mathrm{P}>0.05)$. The TVB-N values in both groups increased during the storage period; the TVB-N values measured in the marinades in sauce were always higher than the TVB-N values of the plain marinades and there was no difference between the groups after the $170^{\text {th }}$ day.

The TVB-N value, which is one of the parameters of deterioration, was $12.53 \pm 0.05 \mathrm{mg} / 100 \mathrm{~g}$ in the plain marinades and the marinades in sauce; however, it was detected to increase to $14.89 \pm 0.72 \mathrm{mg} / 100 \mathrm{~g}$ in the groups in sauce and $15.86 \pm 0.73$ $\mathrm{mg} / 100 \mathrm{~g}$ in the plain groups at the end of the storage period. Based on these results, both groups of marinades were of "very good" product quality in terms of the TVB-N values and they

Table 2. The chemical changes of marinated sea bream during storage period.

\begin{tabular}{|c|c|c|c|c|c|c|c|c|}
\hline \multirow{3}{*}{$\begin{array}{l}\text { Storage time } \\
\text { (day) }\end{array}$} & \multicolumn{8}{|c|}{ Chemical composition in terms of the packing style } \\
\hline & \multicolumn{2}{|c|}{ TVB-N mg/100g } & \multicolumn{2}{|c|}{ TBA mg MA/kg } & \multicolumn{2}{|c|}{ TMA-N mg/100g } & \multicolumn{2}{|c|}{$\mathrm{PV}$ meq/kg } \\
\hline & Sauced & Plain & Sauced & Plain & Sauced & Plain & Sauced & Plain \\
\hline Raw material & $21.81 \pm 0.71$ & $21.81 \pm 0.71$ & $0.19 \pm 0.04$ & $0.19 \pm 0.04$ & $1.92 \pm 0.01$ & $1.92 \pm 0.01$ & $1.62 \pm 0.03$ & $1.62 \pm 0.03$ \\
\hline 0 & $12.53 \pm 0.05$ & $12.53 \pm 0.05$ & $2.87 \pm 0.29$ & $1.42 \pm 0.17$ & $2.81 \pm 0.04$ & $2.83 \pm 0.03$ & $1.82 \pm 0.06$ & $1.82 \pm 0.06$ \\
\hline 15 & $12.55 \pm 0.07$ & $12.08 \pm 0.73$ & $3.48 \pm 0.68$ & $2.35 \pm 0.08$ & $3.00 \pm 0.03$ & $3.05 \pm 0.03$ & $4.04 \pm 0.38$ & $3.78 \pm 0.04$ \\
\hline 30 & $15.72 \pm 1.90$ & $13.90 \pm 1.23$ & $3.56 \pm 0.16$ & $3.57 \pm 0.16$ & $2.79 \pm 0.05$ & $2.84 \pm 0.03$ & $4.24 \pm 0.11$ & $4.05 \pm 0.08$ \\
\hline 50 & $15.81 \pm 0.69$ & $13.46 \pm 0.73$ & $4.79 \pm 0.15$ & $3.88 \pm 0.61$ & $3.04 \pm 0.02$ & $2.94 \pm 0.05$ & $4.63 \pm 0.08$ & $4.49 \pm 0.13$ \\
\hline 80 & $15.83 \pm 0.75$ & $13.47 \pm 0.72$ & $5.32 \pm 0.92$ & $4.07 \pm 0.40$ & $2.04 \pm 0.12$ & $1.95 \pm 0.08$ & $5.34 \pm 0.33$ & $5.05 \pm 0.09$ \\
\hline 110 & $16.21 \pm 0.10$ & $13.64 \pm 0.10$ & $5.69 \pm 0.40$ & $4.69 \pm 0.50$ & $2.31 \pm 0.06$ & $2.25 \pm 0.04$ & $5.74 \pm 0.07$ & $5.56 \pm 0.09$ \\
\hline 140 & $17.72 \pm 1.92$ & $12.86 \pm 0.53$ & $6.48 \pm 0.14$ & $4.95 \pm 0.88$ & $2.14 \pm 0.02$ & $2.11 \pm 0.08$ & $6.23 \pm 0.09$ & $6.15 \pm 0.07$ \\
\hline 170 & $14.43 \pm 0.72$ & $13.97 \pm 0.03$ & $7.10 \pm 0.13$ & $6.13 \pm 0.06$ & $2.42 \pm 0.02$ & $2.34 \pm 0.08$ & $6.98 \pm 0.08$ & $6.92 \pm 0.11$ \\
\hline 200 & $14.89 \pm 0.72$ & $15.86 \pm 0.73$ & $7.99 \pm 0.25$ & $7.06 \pm 0.25$ & $3.12 \pm 0.21$ & $2.97 \pm 0.07$ & $7.45 \pm 0.08$ & $7.23 \pm 0.09$ \\
\hline
\end{tabular}

$\mathrm{n}=3$; (mean value \pm standard deviation). 
were deemed to be consumable and of good quality until the $200^{\text {th }}$ day.

In terms of the quality classification of aquaculture products with respect to the TVB-N values, samples with $25 \mathrm{mg} / 100 \mathrm{~g}$ TVB-N were defined as "very good"; samples with $30 \mathrm{mg} / 100 \mathrm{~g}$ TVB-N were defined as "good"; samples with $35 \mathrm{mg} / 100 \mathrm{~g}$ TVB-N were defined as "marketable"; and the samples with TVB-N more than $35 \mathrm{mg} / 100 \mathrm{~g}$ were defined as "decayed" (Huss, 1988).

In a study conducted by Kaya \& Baştürk (2014) on sea bass marinades, the TVB-N value was determined to be $13.33 \mathrm{mg} / 100 \mathrm{~g}$ in the sauced group and as $13.12 \mathrm{mg} / 100 \mathrm{~g}$ in the plain group at the beginning of the storage; and it was determined as $18.14 \mathrm{mg} / 100 \mathrm{~g}$ in the sauced group and as $16.77 \mathrm{mg} / 100 \mathrm{~g}$ in the plain group at the end of 200 days of storage. Aksu et al. (1997) reported that the TVB-N value of $8.3 \mathrm{mg} / 100 \mathrm{~g}$ in marinated anchovy reached $15.2 \mathrm{mg} / 100 \mathrm{~g}$ at the end of 150 days of storage. Similarly, Dokuzlu (2000) determined that the TVB-N value of $9.8 \mathrm{mg} / 100 \mathrm{~g}$ in anchovy marinades reached $14 \mathrm{mg} / 100 \mathrm{~g}$ at the end of eight months of storage at $4{ }^{\circ} \mathrm{C}$. In another study by Özden \& Baygar (2003), the TVB-N values recorded until the $120^{\text {th }}$ day were reported to be much lower than the limit value for considering the product "consumable". In another study conducted by Varlik et al. (2000) the TVB-N value was reported to be $10.45 \mathrm{mg} / 100 \mathrm{~g}$ on the $150^{\text {th }}$ day. In Gökoğlu et al. (2004) study, the TVB-N value of marinades prepared with $2 \%$ acetic acid $+10 \%$ salt was recorded to increase from $9.3 \mathrm{mg} / 100 \mathrm{~g}$ to $30.2 \mathrm{mg} / 100 \mathrm{~g}$ on the $150^{\text {th }}$ day of storage whereas the TVB-N value of marinades prepared with $4 \%$ acetic acid $+10 \%$ salt was determined to increase from $10.3 \mathrm{mg} / 100 \mathrm{~g}$ to $23.3 \mathrm{mg} / 100 \mathrm{~g}$ at the end of the $150^{\text {th }}$ day and in both cases the TVB-N values stayed within limits of consumable quality. In another study which investigated the shelf life of marinated sardines in tomato sauce (Kılınç \& Çakll, 2005), the shelf life of samples which did and did not undergo pasteurization were reported to be six months. At the end of the $6^{\text {th }}$ month, the TVB-N value increased to $19.13 \mathrm{mg} / 100 \mathrm{~g}$ in pasteurized samples and $28.47 \mathrm{mg} / 100 \mathrm{~g}$ in unpasteurized samples.

The TBA value, determined to be $0.19 \pm 0.04 \mathrm{mg}$ MA $/ \mathrm{kg}$ in the raw material of sea bream, was measured to be $1.42 \pm 0.17 \mathrm{mg} \mathrm{MA} / \mathrm{kg}$ in the plain marinades and $2.87 \pm 0.29 \mathrm{mg} \mathrm{MA} / \mathrm{kg}$ in the marinades in sauce on the $0^{\text {th }}$ day of the completion of maturation, and the difference between the two TBA values was found to be significant $(\mathrm{P}<0.01)$. As can be seen in Table 2, an increase was recorded in the TBA values of both groups and at the end of storage the TBA value of the plain sea bream marinades reached $7.06 \pm 0.25 \mathrm{mg}$ $\mathrm{MA} / \mathrm{kg}$ whereas the TBA value of the sea bream marinades in sauce reached $7.99 \pm 0.25 \mathrm{mg} \mathrm{MA} \mathrm{/} \mathrm{kg.} \mathrm{In} \mathrm{addition,} \mathrm{except}$ for the $30^{\text {th }}$ day of storage, the TBA values measured in the sea bream marinades in sauce were detected to be always higher than the plain marinades.

The TBA value was measured to be $7.99 \pm 0.25 \mathrm{mg}$ $\mathrm{MA} / \mathrm{kg}$ in the group packed in sauce and $7.06 \pm 0.25 \mathrm{mg} \mathrm{MA} /$ $\mathrm{kg}$ in the group packed plainly on the $200^{\text {th }}$ day and these levels are within limits of consumable quality. TBA, which which is used to determine the rancidity in oils, should be less than $3 \mathrm{mg}$ MA / kg in a "very good" material and should not be more than 5 mg MA / kg in a "good" material (Varlık et al., 1993). It is reported that rancidity starts in fish when TBA exceeds $4 \mathrm{mg}$ $\mathrm{MA} / \mathrm{kg}$ and the limit for the product to be deemed consumable is 7-8 mg MA / $\mathrm{kg}$ (Curran et al., 1980).

Erdem et al. (2005) reported that the TBA level in the marinated horse mackerel reached $8.97 \mathrm{mg} \mathrm{MA} / \mathrm{kg}$ on the $120^{\text {th }}$ day of storage and the product decayed. It was reported in a study on anchovy marination that the TBA level was $1.65 \mathrm{mg}$ MA / $\mathrm{kg}$ in the first week and increased to $2.35 \mathrm{mg} \mathrm{MA} / \mathrm{kg}$ in the $10^{\text {th }}$ week (Yapar, 1998). Sallam et al. (2007) marinated Pacific needlefish in various acidic solutions and reported that the raw materials TBA value was $0.37 \mathrm{mg} \mathrm{MA} \mathrm{/} \mathrm{kg}$ and although there was no regular increase in the TBA levels during the 90 days of storage, the product was of good quality. These values are in agreement with the results obtained in this study. Olgunoğlu (2007) reports that they measured the TBA value as $1.16 \mathrm{mg}$ $\mathrm{MA} / \mathrm{kg}$ at the beginning of storage and the TBA level increased regularly over the storage period and reached $4.20 \mathrm{mg} \mathrm{MA} \mathrm{/} \mathrm{kg}$ at the end of seven months of storage. It has been found that these results are lower than the TBA values of the marinades in our study. We think that this difference affecting the quality of marinades in question is caused by the quality of raw material, storage temperature, acid and salt amount in the solution used, and the use of additives.

Another quality factor, the TMA-N value is given in Table 2. in our study, the amount of TMA-N was determined to be $1.92 \pm 0.01 \mathrm{mg} / 100 \mathrm{~g}$ in the raw material, $2.81 \pm 0.04 \mathrm{mg}$ / $100 \mathrm{~g}$ in the groups in sauce, and $2.83 \pm .03 \mathrm{mg} / 100 \mathrm{~g}$ in the plain groups at the beginning of the storage. At the end of the storage period the TMA-N was measured to be $3.12 \pm 0.21 \mathrm{mg}$ / $100 \mathrm{~g}$ in the groups in sauce and $2.97 \pm 0.07 \mathrm{mg} / 100 \mathrm{~g}$ in the plain groups, respectively. These values do not exceed the limit of consumable quality.

The TMA-N value has been reported to be about $1 \mathrm{mg} /$ $100 \mathrm{~g}$ in fresh aquaculture products and $8 \mathrm{mg} / 100 \mathrm{~g}$ in decayed samples (Food and Agriculture Organization of the United Nations, 1986). In addition, in terms of the quality classification of fish products with respect to the TMA-N value, the product is considered "good" with a TMA-N value up to $4 \mathrm{mg} / 100 \mathrm{~g}$, "marketable" with a TMA-N value up to $10 \mathrm{mg} / 100 \mathrm{~g}$, and "decayed" with a TMA-N value equal to or greater than $12 \mathrm{mg}$ / $100 \mathrm{~g}$ (Kundakç1, 1989).

Aksu et al. (1997) conducted a study on the changes occurring during the production of anchovy marinades in various acid-salt concentrations and observed that all samples were of consumable quality after a storage period of 150 days. Sallam et al. (2007) conducted a study to examine the chemical and sensory characteristics of Pacific needlefish (Cololabis saira) and reported that the increase in TMA-N level was considerably slow, and the TMA-N values measured in all study groups at the end of the storage period of 90 days were within limits of consumable quality. In a study by Varlık et al. (2000), which was conducted to determine the shelf life of marinated fish meatballs, 
the authors reported that the TMA-N value was $1.85 \mathrm{mg} / 100 \mathrm{~g}$ at the beginning of storage and reached $2.85 \mathrm{mg} / 100 \mathrm{~g}$ on the $150^{\text {th }}$ day. These results support the results of the $140^{\text {th }}$ day in our study.

In a study conducted by Kılınç \& Çakl (2004), the TMA-N values of pasteurized and unpasteurized sardine marinades in sauce were recorded as $1.71 \mathrm{mg} / 100 \mathrm{~g}, 2.03 \mathrm{mg} / 100 \mathrm{~g}$ and at the end of six months of storage, the values reached $7.73 \mathrm{mg} / 100 \mathrm{~g}$ and $10.86 \mathrm{mg} / 100 \mathrm{~g}$, respectively.

The amount of TMA-N in the fish depends on the season, where the fish were caught, species, muscle type, and processing techniques (Hebard et al., 1982) and therefore we think that the differences in comparison to other studies originate from these factors.

Peroxides are one of the first products formed in the oxidation of unsaturated fatty acids. In this respect, detection of peroxides which are formed at the initial stages of rancidity is generally used as an indicator of quality. Peroxide value (PV) is an indicator of oxidation of fats and oils; it is a measure of the amount of active oxygen in the oils and equivalent to the amount of peroxide oxygen per 1 kilogram of fat or oil which is expressed in units of milliequivalents (Yapar \& Erdöl, 1999).

Peroxide value was detected to be $1.62 \pm 0.03 \mathrm{meq} / \mathrm{kg}$ in the sea bream raw material and increased to $1.82 \pm 0.06 \mathrm{meq} / \mathrm{kg}$ in the plain marinades and $1.82 \pm 0.06 \mathrm{meq} / \mathrm{kg}$ in the marinades in sauce after maturation; however, the difference between the groups was not statistically significant $(\mathrm{P}>0.05)$. The most important increase during the storage period occurred between $0^{\text {th }}-15^{\text {th }}$ days, the difference between groups were statistically significant for each period $(\mathrm{P}<0.01)$; and on the $170^{\text {th }}$ day, peroxide values of the plain marinades and the marinades in sauce were determined to be considerably similar. In addition, a statistically significant difference was found between the groups depending on the storage time $(\mathrm{P}<0.01)$.

In a "very good" quality material, peroxide value should be lower than $2 \mathrm{mmol} \mathrm{O}_{2} / \mathrm{kg}$ oil (= $4 \mathrm{meq} / \mathrm{kg}$ ) and it should not be higher than $5 \mathrm{mmol} \mathrm{O}_{2} / \mathrm{kg}$ oil (= $\left.10 \mathrm{meq} / \mathrm{kg}\right)$ in a "good" quality material; the limit for "consumable quality" was reported to be $10 \mathrm{mmol} \mathrm{O}_{2} / \mathrm{kg}$ (= $20 \mathrm{meq} / \mathrm{kg}$ ) (Varlık et al., 1993).
Olgunoğlu (2007) reported that they monitored the PV of anchovy marinades stored for seven months and the values changed over time. The PV which was recorded as 18.7 meq / $\mathrm{kg}$ at the end of the storage period is considerably higher than the PV observed in this study; however, it is regarded as similar since it is still within limits of consumable quality.

In our study, the changes in sensory characteristics such as appearance, flavour and texture were assessed on marinated sea bream from the beginning of storage until the $200^{\text {th }}$ day and the results obtained are given in Table 3 .

According to the results obtained, the plain sea bream marinade was determined to be "very good" from the beginning of the storage until the $50^{\text {th }}$ day, and "good" between $80^{\text {th }}-200^{\text {th }}$ days. On the other hand, the sea bream marinades in sauce was recorded to remain "very good" until the $80^{\text {th }}$ day and "good" between $110^{\text {th }}-200^{\text {th }}$ days.

According to one of the sensory criteria, the flavour assessment of sea bream marinades, the interaction between packing type and storage time was found to be significant $(\mathrm{P}<0.005)$. Sea bream marinades packed plainly were determined to be "very good" at the beginning of the storage period and remained to be "good" from the $15^{\text {th }}$ day until the end of storage. On the other hand, according to the assessment of panelists, the sea bream marinades in sauce was determined to remain of "very good" quality until the $50^{\text {th }}$ day and of "good" quality between $80^{\text {th }}-200^{\text {th }}$ days.

The texture structure, which was determined to be $3.80 \pm 0.45$ at the beginning of the storage in both plain marinades and marinades in sauce, decreased to $2.00 \pm 0.71$ in the plain group and $2.20 \pm 0.84$ in the group in sauce at the end of the $200^{\text {th }}$ day. The product was appropriate in terms of firmness until the $110^{\text {th }}$ day and was regarded acceptable from the $140^{\text {th }}$ day onwards.

As a result of the study that we conducted, the sea bream marinades stored at $+4 \pm 1{ }^{\circ} \mathrm{C}$ remained of consumable quality until the $200^{\text {th }}$ day and it was concluded that they could be considered as an alternative product. Therefore marination process can be used as a safe method for preservation of sea bream.

Table 3. The sensory changes of marinades during storage period.

\begin{tabular}{|c|c|c|c|c|c|c|}
\hline \multirow{2}{*}{ Storage time (day) } & \multicolumn{2}{|c|}{ Appearance } & \multicolumn{2}{|c|}{ Flavour } & \multicolumn{2}{|c|}{ Texture } \\
\hline & Sauced & Plain & Sauced & Plain & Sauced & Plain \\
\hline 0 & $8.60 \pm 0.55$ & $8.00 \pm 1.00$ & $7.60 \pm 0.55$ & $7.20 \pm 0.84$ & $3.80 \pm 0.45$ & $3.80 \pm 0.45$ \\
\hline 15 & $8.00 \pm 0.71$ & $7.60 \pm 0.55$ & $7.80 \pm 0.55$ & $6.60 \pm 0.55$ & $3.40 \pm 0.55$ & $3.40 \pm 0.55$ \\
\hline 30 & $7.60 \pm 0.55$ & $7.00 \pm 1.00$ & $7.60 \pm 0.55$ & $6.40 \pm 0.55$ & $3.40 \pm 0.55$ & $3.20 \pm 0.84$ \\
\hline 50 & $7.40 \pm 0.55$ & $6.60 \pm 0.55$ & $7.20 \pm 0.84$ & $6.00 \pm 0.71$ & $3.00 \pm 0.00$ & $2.60 \pm 0.55$ \\
\hline 80 & $6.80 \pm 0.45$ & $5.40 \pm 0.55$ & $6.60 \pm 0.89$ & $5.40 \pm 0.55$ & $2.80 \pm 0.45$ & $2.60 \pm 0.55$ \\
\hline 110 & $6.40 \pm 0.55$ & $5.60 \pm 0.55$ & $6.20 \pm 0.84$ & $5.40 \pm 0.55$ & $2.80 \pm 0.45$ & $2.60 \pm 0.55$ \\
\hline 140 & $5.80 \pm 0.84$ & $5.20 \pm 0.45$ & $5.40 \pm 0.55$ & $4.80 \pm 0.84$ & $2.40 \pm 0.55$ & $2.00 \pm 0.71$ \\
\hline 170 & $5.60 \pm 0.55$ & $4.60 \pm 0.55$ & $5.20 \pm 0.84$ & $4.40 \pm 0.55$ & $2.20 \pm 0.84$ & $2.00 \pm 0.71$ \\
\hline 200 & $5.20 \pm 0.84$ & $4.40 \pm 0.55$ & $4.80 \pm 0.84$ & $4.40 \pm 0.55$ & $2.20 \pm 0.84$ & $2.00 \pm 0.71$ \\
\hline
\end{tabular}

$\mathrm{n}=5$; (mean value \pm standard deviation). 


\section{Conclusions}

This study concluded that marination of sea bream in solutions containing $11 \%$ salt $+3.5 \%$ acetic acid can extend the shelf life of the products during storage at $4{ }^{\circ} \mathrm{C}$. As a result of the study conducted, consumable quality of the marinade samples prepared using sunflower oil and sauces prepared with sunflower oil remained until the 200th day. The sea bream marinades stored at $+4 \pm 1{ }^{\circ} \mathrm{C}$ and it was concluded that they could be considered as an alternative product. Therefore marination process can be used as a safe method for preservation of sea bream.

\section{Acknowledgements}

This study is a summary of Gülderen Kurt Kaya’s PhD thesis. The Scientific Research Projects Administration Unit of Mersin University supported this research

\section{References}

Aksu, H., Erkan, N., Çolak, H., Varlik, C., Gökoğlu, N., \& Uğur, M. (1997). Some changes in anchovy marinades during production in different acid-salt concentrations and determination of shelf life. Yüzüncü Yll University Journel of Veterinary Animal Husbandry, 8, 86-90.

American Oil Chemists Society - AOAS. (1994). Official methods and recommended practices of the american oil chemists society. Champaign: American Oil Chemists Society.

Antonacopoulos, N., \& Vyncke, W. (1989). Determination of volatile basic nitrogen in fish: a third collaborative study by the West European Fish Technologists Association (WEFTA). Zeitschrift fur Lebensmittel-Untersuchung und -Forschung, 189(4), 309-316. http:// dx.doi.org/10.1007/BF01683206.

Bligh, E. G., \& Dyer, W. J. A. (1959). A rapid method of total lipid extraction and purification. Canadian Journal of Biochemistry and Physiology, 37(8), 911-917. http://dx.doi.org/10.1139/o59-099. PMid:13671378

Cabrer, A. I., Casales, M. R., \& Yeannes, M. I. (2002). Physical and chemical change in anchovy (engraulis anchoita) flesh during marination. Journal of Aquatic Food Product Technology, 11(1), 19-31. http://dx.doi.org/10.1300/J030v11n01_03.

Cadun, A., Çaklı, Ş., \& Kışla, D. (2005). A study of marination of deepwater pink shrimp (Parapenaeus longirostris, Lucas, 1846) and its shelf life. Food Chemistry, 90(1-2), 53-59. http://dx.doi. org/10.1016/j.foodchem.2004.03.024.

Cadun, A., Kışla, D., \& Çaklı, Ş. (2008). Marination of deep-water pink shrimp with resemary extractand the determination of its shelflife. Food Chemistry, 109(1), 81-87. http://dx.doi.org/10.1016/j. foodchem.2007.12.021.

Curran, C. A., Nicoladies, L., Poulter, R. G., \& Pors, J. (1980). Spoilage of fish from hongkong at different storage temperatures. Tropical Science, 22, 367-382.

Dokuzlu, C. (2000). Shelf-life of the marinated local anchovies. Journal of Faculty of Vertinary Medicine, 19, 45-49.

Erdem, E. M., Bilgin, S., \& Çağlak, E. (2005). Quality changes of processed with marinade, brine and spice horse mackerel (Trachurus mediterraneus) during storage. Ondokuz Mayıs University Journal of the Faculty of Agriculture, 20(3), 1-6.
Erkan, N., \& Özden, Ö. (2007). Proximate composition and mineral contents in aqua cultured sea bass (Dicentrarchus labrax), sea bream (Sparus aurata) analyzed by ICP-MS. Food Chemistry, 102(3), 721725. http://dx.doi.org/10.1016/j.foodchem.2006.06.004.

Food and Agriculture Organization of the United Nations - FAO. (1986). Food and nutrition paper manuals of food quality control food analysis: quality, adulteration, and tests of identity. Rome: Food and Agriculture Organization of the United Nations.

Gökoğlu, N., Cengiz, E., \& Yerlikaya, P. (2004). Determination of the shelf life of marinated sardina (Sardina pilchardus) stored at $4{ }^{\circ} \mathrm{C}$. Food Control, 15(1), 1-4. http://dx.doi.org/10.1016/S09567135(02)00149-4.

Grigorakis, K., Taylor, K. D. A., \& Alexis, M. N. (2003). Organoleptic and volatile aroma compounds comparision of wild and cultured gilthead sea bream (Sparus aurata): sensory differences and possible chemical basis. Aquaculture, 225(1-4), 109-119. http://dx.doi. org/10.1016/S0044-8486(03)00283-7.

Hebard, C.E., Flick, G.J. \& Martin, R.E. (1982). Occurrence and significance oftrimethylamine oxide and its derivatives in fish and shellfish. Introduction to Fish Technology, 149-182.

Huss, H. H. (1988). Fresh fish quality and quality changes. Rome: Food and Agriculture Organization of the United Nations.

James, C. S. (1995). Analytical chemistry of foods. London: Blackie Academic \& Professsional.

Kaya, K. G., \& Baştürk, Ö. (2014). Organoleptıc and chemical changes during storage of sea bass marınades (Dicentrarchus labrax L., 1758). Journal of Food Processing and Preservation, 38(3), 1072-1079. http:// dx.doi.org/10.1111/jfpp.12065.

Kılınç, B., \& Çaklı, Ş. (2004). Chemical, microbiological and sensory changes in thawed frozen fillets of sardina (Sardina pilchardus) during marination. Food Chemistry, 88(2), 275-280. http://dx.doi. org/10.1016/j.foodchem.2004.01.044.

Kılınç, B., \& Çaklı, Ş. (2005). Determination of the shelf life of sardina (Sardina pilchardus) marinades in tomato sauce stored at $4{ }^{\circ} \mathrm{C}$. Food Control, 16(7), 639-644. http://dx.doi.org/10.1016/j. foodcont.2004.07.004.

Kundakçı, A. (1989). The effect of preincubation conditions of gray mullet and blue fish to the quality. Ege University Journal of Fisheries \& Aquatic Sciences, 6, 23-24.

Ludorff, W., \& Meyer, V. (1973). Fish and fisher products. Hamburg: Paul PareyVerlag.

Mattissek, R., Shengel, F. M., \& Steiner, G. (1988). Lebensmittel-Analytick. Berlin: Springer Verlag.

Olgunoğlu, I. A. (2007). Sensory chemical and microbiological change of marinated anchovy (Engraulis engrasicholus) (Tese de doutado). Institute of Nautral and Applied Sciences, University of Çukurova, Balcalı.

Özden, Ö., \& Baygar, T. (2003). The effect of different packaging methods on some quality criteria of marinated fish. Turkish Journal of Veterinary and Animal Sciences, 27, 899-906.

Özden, Ö. (2005). Change in amino acid and fatty acid composition during shelf-life of marinated fish. Journal of the Science of Food and Agriculture, 85(12), 20015-20020. http://dx.doi.org/10.1002/jsfa.2207.

Pala, M., \& Sayg1, Y. B. (1987). Catering Uygulamaları: Risk ve Gelecek Perspektif. Gida Dergisi, 12, 3-11.

Sallam, K. H. I., Ahmed, A. M., Elgazzar, M. M., \& Eldaly, E. A. (2007). Chemical quality and sensory attributes of marinated pacific 
saury (Cololabis saira) during vacuum-packaged storage at $4{ }^{\circ} \mathrm{C}$. Food Chemistry, 102(4), 1061-1070. http://dx.doi.org/10.1016/j. foodchem.2006.06.044.

Schormuller, J. (1968). Handbook of food chemistry (Band III/2). New York: Springer-Verlag.

Tarladgis, B. G., Watts, B. M., Younathan, M. S., \& Dugan, L., Jr (1960). Distilation method for the quantitative determination of malonaldehyde in rancid foods. Journal of the American Oil Chemists' Society, 37(1), 44-48. http://dx.doi.org/10.1007/BF02630824.

Varlik, C., Erkan, N., \& Özden, Ö. (2007). Basic quality control for seafood. İstanbul: İstanbul University.
Varlik, C., Erkan, N., Metin, S., Baygar, T., \& Özden, Ö. (2000). Determination of the shelf-life of marinated fish balls. Turkish Journal of Veterinary and Animal Sciences, 24, 593-597.

Varlik, C., Uğur, M., Gökoğlu, N., \& Gün, H. (1993). Principles and methods of quality control in seafood. İstanbul: Food Technology Association.

Yapar, A., \& Erdöl, M. (1999). Changes in some properties of whiting liver oil stored in a refrigerator. Turkish Journal of Veterinary and Animal Sciences, 23, 333.

Yapar, A. (1998). Some quality changes in anchovy (Engraulis encrasicolus) marinades produced by using two different ripening solutions. Ege University Turkish Fisheries, 15, 1-7. 